\title{
As escolas étnicas polonesas no estado do Paraná e as leis de nacionalização do ensino (1889-1930)
}

\author{
Rodrigo Boçoen* \\ Alboni Marisa Dudeque Pianovski Vieira**
}

\begin{abstract}
Resumo
Este artigo tem como objetivo, analisar as formas encontradas pelas escolas étnicas polonesas para adaptarem-se às leis de nacionalização do ensino no estado do Paraná, no período correspondente à Primeira República Brasileira (1889-1930). Essas escolas preservavam as características étnicas do grupo, em especial, a língua polonesa. De natureza bibliográfica e documental, fundamentou-se nos estudos de Wachowicz (2002), Renk (2009) e Certeau (1998), entre outros. Além disso, foi consultada a legislação educacional do período estudado. Como resultado, foi possível observar a existências de tática de adaptação das escolas étnicas às leis de nacionalização de ensino, sem perder, entretanto, suas características étnicas.

Palavras-chave: História da educação; escolas étnicas; imigração polonesa; leis de nacionalização.
\end{abstract}

\section{Polish ethnic schools in the state of Paraná and education nationalization laws (1889-1930)}

\begin{abstract}
This article aims to analyze the ways the Polish ethnic schools found to adapt to the educational nationalization laws in the state of Paraná, in the period corresponding to the First Brazilian Republic (1889-1930). These schools preserved the ethnic characteristics of the group, especially the Polish language. Bibliographically and documentally, it was based on the studies of Wachowicz (2002), Renk (2009) and Certeau (1998), among others. In addition, the educational legislation of the period studied was consulted. As a result, we observed the existence of adaptation tactics of ethnic schools to educational nationalization laws, without losing, however, their ethnic characteristics.
\end{abstract}

Keywords: History of education; ethnic schools; Polish immigration; nationalization laws.

\section{Introdução}

A partir de meados do século XIX, o Brasil conheceu um grande movimento de imigração europeia para dentro de suas fronteiras. A antiga província, mais tarde estado do Paraná, foi uma das mais influenciadas por esse movimento, tendo recebido centenas de milhares de imigrantes das mais variadas nacionalidades, dentre os quais um dos grupos mais numerosos foi o polonês.

Os imigrantes estabeleceram-se inicialmente em áreas pré-determinadas pelo governo, formaram colônias que, muitas vezes, possuíam aspecto homogêneo em relação à nacionalidade da população. Após fixarem-se em suas respectivas propriedades, os imigrantes poloneses reuniam-se para tratar da construção de duas de suas mais importantes instituições: a igreja e a escola (WACHOWICZ, 2002, p. 21). Essa escola possuía a função de preservação da identidade étnica do grupo, principalmente através da manutenção da língua materna (no caso, a língua polonesa). Segundo Renk (2009, p. 63):

Para as famílias eslavas, os filhos deveriam *Endereço eletrônico: rbocoen @ yahoo.com.br

***Endereço eletrônico: alboni@alboni.com estudar em uma escola étnica para aprender o legado cultural do grupo. [...] Em algumas colônias, havia escolas públicas, mas que raramente eram frequentadas pelos descendentes de imigrantes, pois queriam uma escola diferenciada da pública.

Com a eclosão da Primeira Guerra Mundial, entretanto, as atenções das autoridades voltaram-se para as diversas comunidades étnicas estabelecidas no Paraná, o que levou a revisão da legislação relativa aos estrangeiros e suas escolas. Segundo Martins (1989, p. 368): "o governo percebe que desleixara criminosamente um setor que deveria ter merecido seus melhores cuidados: o do ensino". O governo atribuiu à escola "a incumbência de formar o sentimento de pertencimento à nação (sentimento de brasilidade) por meio de medidas políticas" (RENK, 2009, p. 14). Surgiu nesse período projetos como o "Código de Ensino", de 1917 (PARANÁ, 1917), a Lei n ${ }^{\circ} 2005$, de 1920 (PARANÁ, 1921), e a Lei $\mathrm{n}^{\circ}$ 2157, de 1922 (PARANÁ, 1922), que regulamentam o ensino em língua portuguesa, carga horária mínima, material didático, respeito aos feriados nacionais, dentre outras determinações. 
A criação de novas leis, entretanto, não levou à extinção dessas escolas, como se poderia supor num primeiro momento. Segundo dados de 1937, haviam 167 escolas polonesas no Paraná (e 349 no Brasil), com 6.296 alunos matriculados. Destas escolas, apenas 14 possuíam seu ensino totalmente em língua portuguesa (WACHOWICZ, 2002, p. 72).

Tendo em vista esses dados, o objetivo deste artigo é analisar as formas pelas quais as escolas étnicas polonesas adaptaram-se às leis de nacionalização do ensino, no estado do Paraná, no período correspondente à Primeira República Brasileira (1889-1930). Para isso, buscou-se inicialmente compreender melhor as escolas étnicas polonesas, além de conhecer a política de nacionalização do ensino implementada pelos governos paranaenses, no período em questão, para então analisar as táticas encontradas nas escolas étnicas para adaptarem-se a essa política e os efeitos produzidos em sua cultura escolar.

A expressão "escola étnica", no âmbito deste trabalho, será utilizada conforme proposta por Renk (2009, p. 12):

[...] designando as escolas que ministravam aulas em língua estrangeira ou de forma bilíngue. Essas escolas eram denominadas pelo governo estadual como escolas de estrangeiros. Não eram escolas nos moldes dos países de origem, mas escolas que aqui foram criadas pelos grupos étnicos e poderiam ter elementos de manutenção da identidade étnica, principalmente a língua e a cultura de origem, mas que certamente haviam incorporado elementos da cultura nacional ou mesmo prescrições legais brasileiras.

O presente artigo constitui-se, essencialmente, de um estudo bibliográfico sobre o tema em questão. Para tanto, foi fundamental a consulta a autores como Renk (2009) e Wachowicz (2002), que tratam das escolas da colonização polonesa; Certeau (1998), que traz as definições de táticas e estratégias; Julia (2001) e Viñao Frago (1995), que trabalham com a questão da cultura escolar. Todavia, também foram consultadas fontes históricas, em especial a legislação educacional do período, cuja análise em muito enriqueceu este trabalho.

\section{Cultura escolar e História da Educação: aspectos teóricos}

A ascensão de uma nova História Cultural trouxe para a História da Educação, a ampliação das possibilidades de análises, estimulando o trabalho com diferentes técnicas, fontes e campos de pesquisa. Uma nova possibilidade de pesquisa que ganhou corpo na História da Educação é a relativa à "cultura escolar".

A cultura escolar pode ser descrita como "um conjunto de normas que definem conhecimentos a ensinar e condutas a inculcar, e um conjunto de práticas que permitem a transmissão desses conhecimentos e a incorporação desses comportamentos" (JULIA, 2001, p. 10, grifo do autor).

Tal conjunto de normas e práticas não é imutável, podendo variar segundo as épocas. Portanto, a cultura escolar deve ser estudada com "a análise precisa das relações conflituosas ou pacíficas que ela mantém, a cada período de sua história, com o conjunto das culturas que lhe são contemporâneas: cultura religiosa, cultura política ou cultura popular" (JULIA, 2001, p. 10).

Ainda nesse sentido:

[...] a cultura escolar é toda a vida escolar: atos e ideias, mentes e corpos, objetos e condutas, modos de pensar, dizer e fazer. O que acontece é que neste conjunto há alguns aspectos que são mais relevantes que outros, no sentido de que são elementos organizadores que a conformam e definem (VIÑAO FRAGO, 1995, p. 69) ${ }^{1}$.

Para o mesmo autor, os "elementos organizadores" da vida escolar teriam seus principais representantes no espaço e no tempo escolar. O espaço escolar nunca é neutro de significados, sendo um elemento que se comunica e, portanto, educa. Já o tempo escolar é algo diverso, concomitantemente individual e institucional, construído socialmente (VIÑAO FRAGO, 1995, p. 69-72).

Uma das grandes dificuldades, nesse tipo de pesquisa, está na busca pelas fontes. Conforme indaga Julia (2001, p. 15): "a história das práticas culturais é, com efeito, a mais difícil de se reconstituir porque ela não deixa traço: o que é evidente em um dado momento tem necessidade de ser dito ou escrito?". A falta de documentos escritos leva o historiador a buscar outros tipos fontes e documentos, no sentido amplo atribuído por Le Goff (1992): documentos escritos, ilustrados, transmitidos pelo som, imagem ou qualquer outra maneira. Conforme nos lembra Julia (2001, p, 19): "as fontes podem ser encontradas se temos a 
tenacidade de ir procurá-las".

Mogarro (2006) lista alguns materiais que podem se constituir em fontes históricas para a pesquisa sobre a história das instituições escolares e, num sentido amplo, para a História da Educação: textos legais, estatísticas oficiais, relatórios técnicos elaborados por inspetores, reitores e diretores de escolas, documentos administrativos e pedagógicos, publicações exteriores à escola (livros, artigos de jornais e revistas, entre outros), equipamentos e mobiliário escolar, materiais didáticos, trabalhos escolares de alunos (encontrados com maior frequência em acervos particulares), fotografias, dentre outros exemplos.

Uma vez em posse das fontes, entra em ação o trabalho do historiador na análise desse material. Segundo Vieira (2013, p. 68):

[...] o historiador, no trabalho com as fontes documentais, busca uma aproximação do real que the possibilite encontrar as respostas para suas dúvidas e questões. Isso não significa que as fontes o conduzam à verdade ou que os fatos tenham ocorrido da forma como mencionada nos documentos, porém poderão conduzi-lo a uma interpretação em que se perceba coerência entre o que o documento traz e o que a partir dele se constrói.

Ainda nesse sentido, Viñao Frago (1995) afirma que:

[...] se a realidade considerada é sempre complexa e se o historiador já desistiu da pretensão de produzir o relato, descrição e análise da verdade total e definitiva [...], a posição na qual se situa e da qual olha ocupa um lugar central na operação histórica. Tal posição ou enfoque depende, entre outros aspectos, das fontes e do tema objeto de análise: é, em todo caso, uma opção pessoal entre várias possíveis e mais ou menos frutíferas (VIÑAO FRAGO, 1995, p. 74). ${ }^{2}$

Portanto, uma pesquisa histórica não deve pretender construir um relato verdadeiro e definitivo do passado, mas sim aproximar-se de uma interpretação coerente do que relatam as fontes.

\section{Estratégias e táticas na História da Educação}

$\mathrm{Na}$ pesquisa em História da Educação, especialmente quando as políticas educacionais são objetos de estudo, é grande a tentação em confiar plenamente nas informações transmitidas pelos documentos escritos, sobretudo aqueles de caráter oficial. Entretanto, como nos lembra Julia (2001, p. 15), convém:

[...] recontextualizar as fontes das quais podemos dispor, estar conscientes de que a grande inércia que percebemos em um nível global pode estar acompanhada de mudanças muito pequenas que insensivelmente transformam o interior do sistema; convém ainda não nos deixarmos enganar inteiramente pelas fontes, mais frequentemente normativas, que lemos.

Tal precaução em relação às fontes oficiais e normativas, representações elaboradas por um poder central, na pesquisa histórica, é ressaltada em Certeau (1998), quando afirma que:

[...] a presença e a circulação de uma representação [...] não indicam de modo algum o que ela é para seus usuários. É ainda necessário analisar a sua manipulação pelos praticantes que não a fabricam. Só então é que se pode apreciar a diferença ou a semelhança entre a produção da imagem e a produção secundária que se esconde nos processos de sua utilização (CERTEAU, 1998, p. 40).

Essa diferenciação entre produção e utilização de determinada representação fica melhor explicada quando Certeau nos apresenta os conceitos de estratégias e táticas. Para o autor, a "estratégia" é definida como o cálculo das relações de forças que se torna possível quando um sujeito, detentor de algum tipo de poder, "[...] postula um lugar capaz de ser circunscrito como um próprio e, portanto, capaz de servir de base a uma gestão de suas relações com uma exterioridade distinta" (CERTEAU, 1998, p. 46, grifo do autor).

Já a "tática" é uma:

[...] ação calculada que é determinada pela ausência de um próprio. [...] A tática não tem por lugar senão o do outro. E por isso deve jogar com o terreno que lhe é imposto tal como o organiza a lei de uma força estranha. [...] Ela opera golpe por golpe, lance por lance. Aproveita as "ocasiões" e delas depende, sem base para estocar benefícios, aumentar a propriedade e prever saídas. O que ela ganha não se conserva. Este não-lugar lhe permite sem dúvida mobilidade, mas numa docilidade aos azares do tempo, para captar no voo as possibilidades oferecidas por um instante. Tem que utilizar, vigilante, as falhas que as

Horizontes, v. 35, n. 2, p. 59-68, mai./ago. 2017 
conjunturas particulares vão abrindo na vigilância do poder proprietário (CERTEAU, 1998, p. 100-101).

Portanto, estratégias são os comportamentos dos detentores do poder, enquanto as táticas são os modos de fazer daqueles que não detêm tal poder, mas que não permanecem submissos. Segundo o autor, "[...] a tática é a arte do fraco. [...] 'Quanto mais fracas as forças submetidas à direção estratégica, tanto mais esta estará sujeita à astúcia'. Traduzindo: tanto mais se torna tática" (CERTEAU, 1998, p. 101).

Outra característica que diferencia os comportamentos estratégicos e táticos relaciona-se à forma de ação:

[...] as estratégias são portanto ações que, graças ao postulado de um lugar de poder [...], elaboram lugares teóricos (sistemas e discursos totalizantes), capazes de articular um conjunto de lugares físicos onde as forças se distribuem. [...] As táticas são procedimentos que valem pela pertinência que dão ao tempo - às circunstâncias que o instante preciso de uma intervenção transforma em situação favorável [...]. Sob este aspecto, a diferença entre umas e outras remete a duas opções históricas em matéria de ação e segurança [...]: as estratégias apontam para a resistência que o estabelecimento de um lugar oferece ao gasto do tempo; as táticas apontam para uma hábil utilização do tempo, das ocasiões que apresenta e também dos jogos que introduz nas fundações de um poder (CERTEAU, 1998, p. 102).

Por não contarem com o estabelecimento de um lugar, as táticas tornam-se mais ágeis e flexíveis, comparadas às estratégias. Por meio de sua ação ao longo do tempo, elaboram maneiras de burlar o poder estabelecido, atuando em suas fundações mesmo que não pretendam, necessariamente, subverter esse poder.

\section{Escolas étnicas}

Entre todos os países americanos, foi no Brasil que se criou o maior número de escolas étnicas. O número mais expressivo é o de escolas alemãs, estimadas em 1.579 no ano de 1937, seguido das escolas italianas, com 396 escolas existentes em 1913 e cerca de 167 na década de trinta, e das escolas de etnia polonesa, com 349 escolas no final da mesma década, sendo 167 delas no estado do Paraná (KREUTZ, 2000, p. 160;
WACHOWICZ, 2002, p. 66). Segundo Kreutz (2000), esses números refletem a tradição escolar trazida pelos imigrantes, que estabeleceram redes escolares próprias num período em que o sistema escolar brasileiro era altamente deficitário, com mais de $80 \%$ da população analfabeta.

A criação de escolas étnicas pode ser observada entre grupos de diferentes nacionalidades espalhados pelo território brasileiro, resultando numa rica diversidade de trajetórias, modelos e particularidades. Entretanto, podemos observar alguns elementos em comum que nos ajudam a chegar a um conceito de "escola étnica":

[...] as escolas étnicas tinham sua existência fora da esfera do Estado e não se constituíam em uma organização monolítica. Elas tinham uma organização própria que não era moldada pelas escolas públicas e nem pelas escolas dos países de origem. Apesar da sua quantidade, essas escolas não constituíam uma rede única ou homogênea de saberes transmitidos ou de sistematização das práticas pedagógicas. E foram incorporando as prescrições ditadas pelo Estado à medida que eram obrigadas pela legislação (RENK, 2009, p. 18-19).

As escolas étnicas podem ser classificadas em três tipos, segundo suas formas de organização: as escolas comunitárias, ou sociedades-escolas, construídas e mantidas pela iniciativa da comunidade, funcionando em espaços próprios, onde o ensino era na língua de origem do grupo e o professor era, geralmente, um membro da comunidade; escolas étnicas religiosas, administradas por congregações religiosas oriundas dos países de origem, ensinavam na língua de origem do grupo e incluíam o ensino religioso; e escolas étnicas subvencionadas, que eram escolas comunitárias nas quais, a partir de 1918, o pagamento do professor era efetuado pelo governo estadual ou federal, em virtude das primeiras tentativas de nacionalização do ensino, exigindo-se ainda o ensino em língua portuguesa e um número mínimo de 20 alunos. Dentre esses diferentes tipos de escola, uma característica em comum destacavase: o ensino ministrado na língua materna do grupo (ou, em alguns casos, o bilinguismo), além da manutenção da identidade cultural do grupo (RENK, 2009, p. 19-20).

Uma grande dificuldade comum às escolas de iniciativa comunitária era o preenchimento do cargo de professor. Como nos primeiros anos da imigração os professores com formação profissional 
eram raros, se escolhia para a função um indivíduo, dentre os próprios colonos, "que fosse considerado mais desembaraçado e capacitado e que soubesse, ao menos satisfatoriamente, ler e escrever. Assim os colonos transformavam, num passe de mágica, um rude campônio em pedagogo improvisado" (WACHOWICZ, 2002, p. 27). Esse professor improvisado interrompia seu trabalho diário na lavoura para ensinar, além de ter a incumbência de conservar e limpar a escola. Em troca, o professor recebia uma pequena taxa a ser paga pelos pais, por cada aluno que frequentava a escola.

Apenas a partir da década de 1920 acontece a criação de organizações mais amplas, preocupadas com a questão escolar, resultados das iniciativas das congregações religiosas e do recém-criado Consulado da Polônia. Entre as atividades destas organizações encontram-se a contratação e qualificação de professores e a produção e publicação de material didático, tanto em língua polonesa como bilíngues (WACHOWICZ, 2002).

\section{A legislação educacional paranaense e a nacionalização do ensino}

Em 1834, com o Ato Adicional à Constituição do Império, o governo central brasileiro transferia a incumbência de cuidar das escolas primárias e secundárias para os governos provinciais (SAVIANI, 2007, p. 129). Nem mesmo a mudança para o regime republicano mudou a legislação nesse aspecto. Tomando a situação das escolas étnicas, por exemplo: “Até a década de 30 não havia no Brasil uma política em nível nacional sobre a nacionalização das comunidades consideradas como estrangeiras, mas, sim, políticas estaduais que visavam ao uso da língua nacional nas escolas [...]" (RENK, 2004, p. 79).

Entretanto, mesmo tais políticas estaduais demoraram a surgir no Paraná, e a legislação educacional existente, com relação às escolas particulares, mostrava-se muito vaga. O Decreto $\mathrm{n}^{\circ}$ 35 de 9 de fevereiro de 1895 (PARANÁ, 1929), por exemplo, estabelecia em seu artigo $4^{\circ}$ que: "Os estabelecimentos de ensino particular são completamente livres, devendo, porem, os respectivos Directores, fornecer às autoridades do ensino, as informações que ellas reclamarem".

Outro Decreto, o de $n^{\circ}$ 93, de 11 de março de 1901 (PARANÁ, 1901), estabelecia, em seu artigo $2^{\circ}$, como "inteiramente livre aos particulares e associações o exercício do ensino primário, secundário ou superior". Pelo artigo seguinte: "Os estabelecimentos particulares de instrucção só estão sujeitos à hygiene, moralidade e estatística".

Em relação à nacionalização do ensino, encontramos no artigo 20 da Lei $\mathrm{n}^{\mathbf{0}} 365$, de 11 de abril de 1900 (PARANÁ, 1901), a obrigatoriedade do ensino em língua nacional para aquelas escolas primárias ou secundárias que recebessem subvenção ou auxílio do governo do Estado. Outra lei que versava sobre esse assunto era a Lei $n^{\circ} 723$ de 03 de abril de 1907 (PARANÁ, 1907), que previa em seu artigo $1^{\circ}$, parágrafo "a", a exigência do ensino em língua nacional nas escolas particulares de instrução primária.

A Lei $n^{\circ}$ 894, de 19 de abril de 1909 (PARANÁ, 1909), reformou diversos aspectos do ensino no Estado. A respeito das escolas particulares, essa lei determinava que:

Art. 82. É livre aos particulares e associações o exercício do ensino primário, secundário, profissional e artístico, em todo o território do Estado, obedecidas as disposições dos artigos seguintes [...].

Art. 83. É obrigatório o ensino da língua nacional nas escolas primárias particulares e nestas, como nos demais estabelecimentos de instrução, de qualquer natureza, o ensino será ministrado em língua vernácula, exceto, quando se tratar do ensino prático de línguas estrangeiras (PARANÁ, 1909).

Embora estabelecendo a obrigatoriedade do ensino em língua vernácula, a legislação supracitada não faz referência à organização curricular das escolas particulares. Segundo Wachowicz (2002, p. 40):

[...] como a lei não especificava o tempo que deveria ser empregado na duração dessas aulas, bem como nas de língua estrangeira, e não havendo interesse por parte das autoridades estaduais na sua execução, essa lei permaneceu olvidada, continuando o ensino particular sujeito apenas ao que estabelecia o decreto $n^{\circ} 93$ de 1901.

As leis existiam apenas no papel, e as comunidades polonesas não tomaram medidas para preparar seus professores a ensinar em língua portuguesa. Para Gluchowski (2005, p. 186), "infelizmente a comunidade menosprezou o perigo que a ameaçava por esse lado, não aproveitou esse período de 'curso suave' e não fez nada para preparar professores adequados, que correspondessem às exigências dos dispositivos 
legais".

Tal "curso suave" encontraria seu fim com a eclosão da Primeira Guerra Mundial. Segundo Wachowicz (2002, p. 39):

[...] uma onda de nacionalismo apoderou-se das autoridades constituídas. Com o grito de 'perigo germânico', lançado pela imprensa nacional, [...] que a eficiente organização da imigração alemã no Brasil poderia possivelmente proporcionar à segurança nacional, levou as autoridades à revisão das leis existentes sobre os estrangeiros.

$\mathrm{Na}$ influência do nacionalismo as autoridades paranaenses criaram, em 1917, o Código de Ensino, através do Decreto ${ }^{\circ} 17$, de 09 de janeiro (PARANÁ, 1917). Este documento determinava que as escolas particulares deviam ensinar Língua Portuguesa, Corografia e História do Brasil, para receberem quaisquer auxílios do Estado.

Outra lei, que regulamentava o ensino da língua portuguesa nas escolas estrangeiras, era a 2005, de 09 de abril de 1920. Esta lei complementava o Código de Ensino de 1917, estabelecia que as aulas das disciplinas em língua vernácula tivessem duração mínima de três horas diárias e, as escolas podiam solicitar ao governo um professor normalista para lecionar tais matérias (PARANÁ, 1920).

Em continuidade a tal processo de nacionalização do ensino no Paraná, entrou em vigor a Lei $\mathrm{n}^{\circ} 2157$, de 08 de abril de 1922, segundo a qual:

Art. 1. É livre aos particulares o exercício do magistério no Estado, observadas as condições da presente lei:

$\S 1^{\circ}$. Nenhum estabelecimento de ensino particular poderá funcionar sem prévio registro gratuito na Inspetoria Geral do Ensino.

$\S 2^{\circ}$. Para a admissão do registro, ao professor ou diretor do estabelecimento, incumbe:

[...]

$2^{\circ}$ ) assumir o compromisso escrito de:

a) respeitar os feriados nacionais;

b) ministrar ou fazer ministrar o ensino em vernáculo, salvo o das línguas estrangeiras;

c) incluir o ensino do vernáculo em 4 aulas por semana, pelo menos, por professores de reconhecida competência;

d) incluir no programa o ensino da Geografia, Corografia e História do Brasil, em 3 aulas semanais;

e) adotar os programas oficiais para o ensino das disciplinas a que se referem as letras c) e d) deste número (PARANÁ, 1922).
Segundo observa Renk (2004, p. 105), por meio dessa lei, o Estado buscava estabelecer maior controle sobre as escolas dos imigrantes, exigindo o ensino em língua portuguesa, o repasse de informações às autoridades e a assinatura de um termo de compromisso dos professores, pelo qual estes dispunham-se a ensinar de acordo com os programas oficiais, numa tentativa de descaracterizar as escolas étnicas.

Entretanto, apesar dos esforços nesse sentido, as escolas estrangeiras continuaram existindo no Brasil, sendo definitivamente fechadas apenas no final da década de 1930, com a nacionalização compulsória do governo Getúlio Vargas. Até então, as escolas étnicas buscavam adaptar seu funcionamento à legislação em vigor, como veremos adiante.

\section{Escolas étnicas: táticas e organização}

Nas escolas criadas pelos próprios grupos imigrantes, o ensino em língua polonesa tornava-se um elemento de manutenção da identidade étnica. Segundo Renk (2009, p. 72):

[...] ao se identificar como escola étnica, a escola se diferenciava das escolas públicas e atendia aos interesses dessas comunidades, tratando-se de uma escola diferenciada. A língua materna era o elemento essencial de manutenção da identidade étnica, pois ela expressa a cultura e as formas de ver o mundo.

$\mathrm{O}$ desejo de manter uma escola que conservasse seus valores culturais sobrepunha-se à simples necessidade de existência de escolas entre as comunidades: "Mesmo com a campanha de nacionalização [...], em algumas comunidades os pais ainda preferiam mandar os filhos para as escolas étnicas ao invés da escola pública. As comunidades não se identificavam com a identidade e cultura nacional e não entendiam o português" (RENK, 2013, p. 22226).

Nesse sentido, diante da ameaça de nacionalização de suas escolas, as comunidades imigrantes buscaram meios de preservar suas características étnicas, mesmo diante dos dispositivos adotados pelas autoridades estaduais, como a legislação e a fiscalização das escolas. Uma das táticas encontradas foi a conciliação do ensino nos dois idiomas, português e polonês.

$\mathrm{Na}$ figura a seguir, por exemplo, observamos os horários de aulas para uma escola polonesa. Embora não seja possível identificar sua 
data, podemos notar que, apesar da maior parte das matérias referir-se à história e à língua polonesa, já se encontravam presentes as disciplinas de "leitura portugueza", "geografia", "chorographia" e "Hist. do Brazil", ao menos uma delas em cada dia da semana. Evidencia-se, assim, uma tentativa de adequação do currículo escolar às novas exigências legais: como observado anteriormente, o Código de Ensino de 1917 determinava o ensino dessas disciplinas para a obtenção de auxílios governamentais. Por outro lado, a presença majoritária de disciplinas específicas das escolas étnicas polonesas denota o esforço na preservação dessas características culturais.

Figura 1 - Horários de aulas de uma escola polonesa

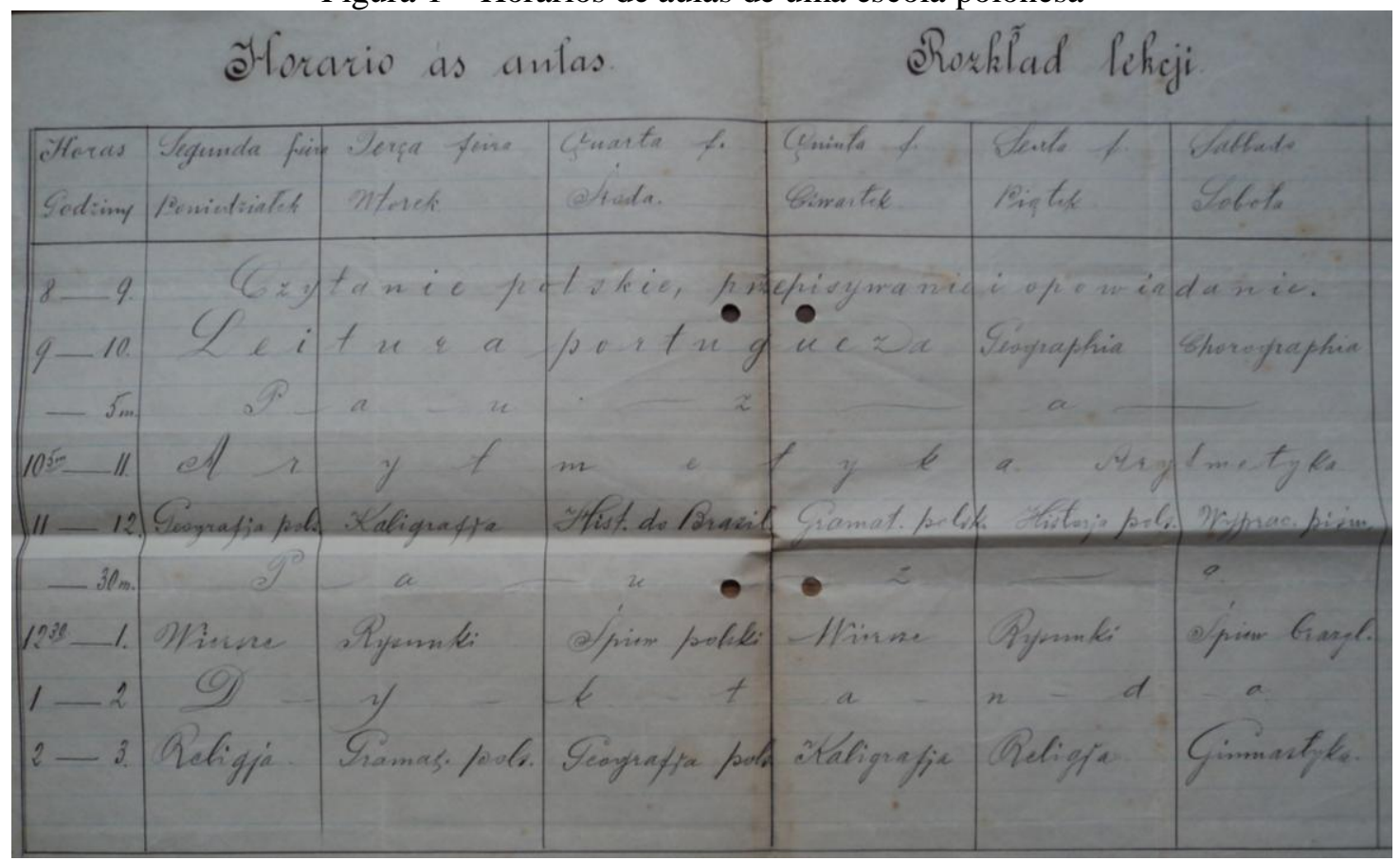

Fonte: Arquivos da Congregação Vicentina, Curitiba.

As escolas polonesas adaptaram seus currículos, embora mantivessem seu caráter étnico. A existência do ensino bilíngue permitiu que, na ocasião das visitas dos Inspetores de Ensino, a escola passasse a impressão de estar se nacionalizando:

Apesar do controle e fiscalização [...], havia mecanismos de "esconder" o que não poderia ser visto. A professora poderia criar estratégias, combinadas com os alunos, que dificultassem o inspetor de perceber algumas ações [...]. Quando vinha o Inspetor de Ensino, os alunos demonstravam o conhecimento da Língua vernácula, dos hinos patrióticos, fazendo-o reconhecer que a escola estava em franco processo de nacionalização dos colonos e dos seus filhos. Mas, distante dos olhos do Inspetor, permaneciam o ensino da cultura da pátria de origem do grupo étnico (RENK, 2013, p. 22.222).

Em 1926 foi editada, em Curitiba, uma cartilha direcionada aos professores das escolas polonesas no Brasil, de autoria de Konstant Lech. Nessa obra, o ensino bilíngue já aparecia como forma de organização recomendada para o trabalho escolar:

O período da manhã destinava-se à parte polonesa do programa, e o da tarde à parte brasileira, de modo que os alunos passavam o dia todo na escola. Pela manhã, eram estudadas a Língua, a Geografia e a História polonesas, além de canções polonesas e religião, nas escolas onde era lecionada [...]. À tarde, além do Português, o currículo destinava-se à Geografia Geral, Aritmética, História Natural, Ginástica e Canto, lecionadas em vernáculo (WACHOWICZ, 2002, p. 83).

Com essa forma de organização, as escolas poderiam ampliar seu público, atendendo os descendentes de imigrantes em horário integral e os alunos brasileiros durante um período do dia. A legislação do período não abordava o bilinguismo, 
sendo possível acreditar que essa prática pedagógica foi uma iniciativa das escolas étnicas para atender às políticas de nacionalização. Nesse sentido:

As formas de fazer revelam como a escola trabalhava com os preceitos legais e ao mesmo tempo precisava inventar uma forma de manterse distinta das escolas públicas. [...] havia incorporação das determinações da legislação em consonância com os objetivos das escolas étnicas (RENK, 2009, p. 103).

Outro espaço de resistência encontrado foram as aulas de catequese. Estas aulas aconteciam fora do espaço escolar e do horário das aulas, sem alarde, conforme combinado entre catequistas e catequizandos (RENK, 2009, p. 155).

No início da década de 1920, surgiram associações, na comunidade polonesa, que buscavam organizar o funcionamento das escolas étnicas, que até então funcionavam de forma isolada. As associações "Cultura" e "Oswiata" (em polonês, Educação), de orientação laica e católica, respectivamente, que atuavam para melhorar as condições de atuação do professorado, forneciam matérias didáticos, criaram bibliotecas fixas e ambulantes, além de dinamizar a atuação da imprensa voltada aos imigrantes (GLUCHOWSKI, 2005).

No contexto da nacionalização do ensino, essas organizações também buscaram meios de preservar o trabalho realizado pelas escolas étnicas, apesar das medidas tomadas pelo governo estadual.

Exemplo disso, foi o ocorrido após a criação da lei no 2157, de 1922 (PARANÁ, 1922), que exigia dos professores o compromisso de lecionar em língua portuguesa, como visto anteriormente. Representantes das escolas polonesas chegaram a um acordo com as autoridades estaduais, adiando a execução da lei em um ano, possibilitando que os professores que atuassem nas escolas étnicas pudessem se preparar adequadamente aos exames de língua portuguesa (WACHOWICZ, 2002).

Organizou-se, então, um "Comitê de Cursos", dirigidos pelo professor Nicéfaro Modesto Falarz, delegado para essa finalidade pelo governo do Estado. Em seu primeiro ano de funcionamento, foram aprovados 56 professores que receberam autorização para lecionar História e Corografia do Brasil e Língua Portuguesa (WACHOWICZ, 2002, p. 48).

\section{Considerações finais}

Durante as primeiras décadas do século $\mathrm{XX}$, a legislação paranaense que regulamentava o funcionamento das escolas dos imigrantes passou por diversas modificações. De textos vagos e nada restritivos, tornaram-se, especialmente com a eclosão da Primeira Guerra Mundial, textos mais rígidos que detalhavam as disciplinas a serem ensinadas, exigia o ensino em língua portuguesa, previa a duração mínima dessas matérias, dentre outras medidas.

À medida que encontravam obstáculos para sua atuação, as escolas étnicas polonesas buscaram meios de organizar seu trabalho, adequando-se às novas exigências sem perder sua singularidade. Essas escolas fabricaram suas táticas de acordo com os recursos que possuíam: desde a adequação de seus currículos que privilegiava o ensino étnico e mantinha as disciplinas obrigatórias ao mínimo exigido pela legislação, até a sistematização do ensino bilíngue, o que possibilitava a criação de mecanismos para esconder do olhar das autoridades o ensino da cultura do grupo.

O surgimento de associações que buscavam organizar o funcionamento das escolas étnicas polonesas, a partir da década de 1920, contribuiu para o processo de adaptação do ensino étnico à nova legislação, em especial no que concerne à preparação dos professores.

Por meio deste artigo, buscou-se trazer uma breve contribuição ao estudo do fenômeno das escolas étnicas. Novas abordagens devem ser realizadas, dentro desse tema, buscando dar voz aos professores, alunos e outros personagens que influenciaram, direta ou indiretamente, o trabalho destas instituições que, apesar de ainda timidamente presentes na historiografia da educação, foram fundamentais para gerações de imigrantes que ajudaram a construir o Paraná tal qual o conhecemos hoje.

\section{Notas}

1 " [...] a cultura escolar es toda la vida escolar: hechos e ideas, mentes y cuerpos, objetos y conductas, modos de pensar, decir y hacer. Lo que sucede es que en este conjunto hay algunos aspectos que son más relevantes que otros, en el sentido de que son elementos organizadores que la conforman y definen" (VIÑAO FRAGO, 1995, p. 69). Usar somente notas de fim: No final do texto e antes das referências, em tamanho de letra 11. As remissões para a nota deverão ser feitas por números arábicos. 
2 "Si la realidad considerada es siempre compleja y si el historiador ha renunciado ya a la pretensión de producir el relato, descripción y análisis de la verdad total y definitiva [...], la posición en la que se sitúa y desde la que mira ocupa un lugar central en la operación histórica. Dicha posición o enfoque depende, entre otros aspectos, de las fuentes y del tema objeto de análisis: es, en todo caso, una opción personal entre varias posibles y más o menos fructíferas" (VIÑAO FRAGO, 1995, p. 74). No final do texto e antes das referências, em tamanho de letra 11. As remissões para a nota deverão ser feitas por números arábicos.

\section{Referências}

CERTEAU, Michel de. A invenção do cotidiano: Artes de fazer. Trad. Ephraim Ferreira Alves. 3. ed. Petrópolis: Vozes, 1998.

GLUCHOWSKI, Kazimierz. Os poloneses no Brasil: subsídios para o problema da colonização polonesa no Brasil. Porto Alegre: Rodycz \& Ordakowski, 2005.

JULIA, Dominique. A cultura escolar como objeto histórico. Revista Brasileira de História da Educação. Campinas, n. 1, p. 9-43, jan./jun. 2001.

KREUTZ, Lúcio. Escolas comunitárias de imigrantes no Brasil: instâncias de coordenação e estruturas de apoio. Revista Brasileira de Educação, n. 15, p. 159-176, set./dez. 2000.

LE GOFF, J. História e memória. Trad. Bernardo Leitão et al. Campinas: Editora da Unicamp,1992.

MARTINS, Wilson. Um Brasil diferente: ensaio sobre fenômenos de aculturação no Paraná. São Paulo: T. A. Queiroz, 1989.

MOGARRO, M. J. Arquivo e Educação. A construção da memória educativa. Sísifo. Revista de Ciências da Educação, 2006, 1, pp. 71-84.

PARANÁ. Decreto $\mathrm{n}^{\mathrm{o}} 35$, de 09 de fevereiro de 1895. Decretos e Regulamentos de 1895-1896. Curityba: Typ. d'A República, 1929.

Lei $\mathrm{n}^{\circ} 365$, de 11 de abril de 1900. Leis, Decretos e Regulamentos do Estado do Paraná -
1900. Curityba: Typ. d'A República, 1901.

. Decreto $\mathrm{n}^{\circ}$ 93, de 11 de março de 1901. Leis, Decretos e Regulamentos de 1901. Curityba: Typ. d'A República, 1901.

Lei $\mathrm{n}^{\circ} 723$, de 03 de abril de 1907. Leis, Decretos e Regulamentos do Estado do Paraná 1907. Curytiba: Typ. D’A República, 1907.

Lei $\mathrm{n}^{\circ}$ 894, de 19 de abril de 1909. Leis e Decretos não Sanccionados. Curytiba: Typ. D'A República, 1909.

Decreto $\mathrm{n}^{\circ}$ 17, de 09 de janeiro de 1917. Collecção de Decretos e Regulamentos de 1917. Coritiba: Typ. d' República, 1917.

Lei ${ }^{\circ}$ 2005, de 09 de abril de 1920. Leis de 1920. Curityba: Typ. d'A República, 1921.

Lei ${ }^{\circ}$ 2157, de 08 de abril de 1922. Leis de 1922. Curityba: Typ. Da República, 1922.

RENK, Valquiria E. A educação dos imigrantes alemães católicos em Curitiba. Curitiba: Champagnat, 2004.

A escolarização da infância nas escolas étnicas eslavas do Paraná: uma experiência singular na História da Educação. In: CONGRESSO NACIONAL DE EDUCAÇÃO - EDUCERE, 11., 2013. Anais... Curitiba: Champagnat, 2013. 1 CDROM.

Aprendi falar português na escola! $\mathrm{O}$ processo de nacionalização das escolas étnicas polonesas e ucranianas no Paraná. 2009. 243 f. Tese (Doutorado) - Universidade Federal do Paraná, Curitiba, 2009.

SAVIANI, Dermeval. História das ideias pedagógicas no Brasil. Campinas: Autores Associados, 2007.

VIEIRA, Alboni Marisa D. Pianovski. Instituições escolares: Memória, fontes, arquivos e novas tecnologias. In: SILVA, João Carlos da (et al.) (Org.). História da Educação: arquivos, instituições escolares e memória histórica. São Paulo: Alínea, 2013, p. 131-155.

VIÑAO FRAGO, Antonio. Historia de la educación 
y historia cultural: posibilidades, problemas, cuestiones. Revista Brasileira de Educação, n. 0, p. 63-82, set./dez. 1995.
WACHOWICZ, Ruy C. As escolas da colonização polonesa no Brasil. Curitiba: Champagnat, 2002.

Sobre os autores:

Rodrigo Boçoen é Mestre em Educação e licenciado em História pela Pontifícia Universidade Católica do Paraná

Alboni Marisa Dudeque Pianovski Vieira é Doutora em Educação, mestre em Educação e em Gestão de Instituições de Educação Superior, licenciada em Pedagogia e bacharel em Direito. Professora do curso de Pedagogia e do Programa de Pós-Graduação (Mestrado e Doutorado) em Educação da Pontifícia Universidade Católica do Paraná - PUCPR.

Recebido em outubro de 2016.

Aprovado em maio de 2017. 